\title{
Rural local institutions and climate change adaptation in forest communities in Cameroon
}

\author{
H. Carolyn Peach Brown ${ }^{1}$ and Denis J. Sonwa ${ }^{2}$
}

\begin{abstract}
Surveys and interviews were used to understand community resilience in forest-dependent communities facing climate change in Cameroon. Surveys of 232 individuals showed a diversity of formal and informal institutions that relate to most aspects of rural life. Although direct activities related to climate change adaptation were limited, the activities and density of membership in rural local institutions could increase the community's adaptive capacity. Twenty-six semistructured interviews were also conducted with representatives of diverse local institutions who had some responsibility for agriculture, forests, conservation, or development. Local governmental institutions had not received any information from the national level and were limited in their knowledge of how to help communities respond to climate change. Although limited in their direct action on climate change, local nongovernmental organizations and international institutions act as bridging institutions with rural communities and could facilitate sharing of knowledge and innovation, thereby fostering resilience. Planning for climate change adaptation in Cameroon needs to build the capacity of diverse local institutions and improve the relationships between local and national-level adaptation planning.
\end{abstract}

Key Words: adaptation; Africa; climate change; community forests; local institutions; resilience

\section{INTRODUCTION}

Africa is considered to be particularly vulnerable to climate change as a result of a degree of change in climate that is higher than the global average, high levels of dependence on natural resources, and a low degree of adaptive capacity (Eastaugh 2010, AMCEN 2011). In many countries of sub-Saharan Africa, the agriculture and forest sectors provide employment for the majority of the population (InterAcademy Council 2004). Agriculture is highly sensitive to climate change, which has the potential to transform food production, especially the patterns and productivity of crop and livestock systems, and to reconfigure food distribution, markets, and access (Schlenker and Lobell 2010, Vermeulen et al. 2012). Forests will also face significant pressure from climate change over the next century, disrupting the important ecological, economic, social, and aesthetic services they provide (Bonan 2008). In Cameroon, the economy is predominantly agrarian and the exploitation of agricultural and other natural resources plays a central role in the country's economic development (Republic of Cameroon 2005). About $80 \%$ of the country's poor live in rural areas and work primarily in agriculture (Molua 2011). In the humid forest zone, these primarily small-holder farmers are also dependent on the forest for food, fuel wood, medicinal plants, and other resources as part of their livelihood strategy (Sonwa et al. 2012). Some feel that poor women may be particularly vulnerable because of their dependence on natural resources and their marginalization from decision-making processes (Demetriades and Esplen 2010, Mwangi et al. 2011).

The resilience of complex social-ecological systems when faced with uncertainty and change stems from a variety of sources (Berkes et al. 2003, Folke 2006, Lebel et al. 2006). Institutions have influenced the livelihoods and adaptation of rural communities in the past. They structure risk and sensitivity to climate hazards, and thereby facilitate or impede individual and collective responses, ultimately shaping the outcomes of such responses (Agrawal 2008, 2010). Rural local institutions contribute to sustainable livelihoods in diverse ways and are important for addressing and mitigating various aspects of insecurity and vulnerability (Uphoff and Buck 2006). Such local institutions, which acquire and store knowledge and experience, as well as create flexibility in problem solving, can increase people's adaptability and resilience (Tompkins and Adger 2004, Walker et al. 2006).

Institutions can be defined as the complexes of norms and behaviors that humans use to organize all forms of repetitive and structured interactions (Ostrom 2005). Although institutions can represent diffuse patterns of behavior, they can also function as organizations or structures of recognized and accepted roles that serve particular purposes (Uphoff and Buck 2006). They exist in the public, private, and civic sectors in the form of membership organizations or cooperatives. Rural producer organizations represent a hybrid category that includes a variety of membership organizations, cooperatives, or private businesses (Uphoff and Buck 2006). Such organizations are often characterized by highly local, specific, and evolving structures and functions depending on the area (Washington-Ottombre and Pijanowski 2013).

Climate change is likely to have an adverse effect on rural livelihood strategies, primarily for those who live in poverty. Institutional capacities at the local level contribute to sustainable livelihoods because they buffer or mitigate those factors that endanger or deprive people of their livelihoods (Uphoff and Buck 2006). Institutions can create the incentive frameworks within which households and collectives choose specific adaptation practices. The linkages of households or social groups in an area to institutions are important because such access will affect the nature of benefits they gain from these institutions (Agrawal 2008). Davidson-Hunt (2006) suggests that heuristic and adaptive learning operates through individual actors, with the recognition that these actors are embedded in social networks of 
communication that provide the architecture for social learning processes. Individuals and groups learn through access to novel information via their social networks, which also influence the way information is processed. In addition, local institutions mediate external interventions that can reinforce or undermine adaptation practices (Agrawal 2008). Planning for climate change adaptation, therefore, needs to promote the capacity of local institutions and improve the relationships between local and national-level adaptation planning (Agrawal et al. 2012).

In the forest zone of Cameroon, recent studies have indicated that climate change is already having an adverse impact on the livelihood strategies of rural people (Bele et al. 2013). Drought, changing seasons, erratic rainfall patterns, heavy rainfall, and strong winds are among the main climate-related disturbances perceived by local people. Although some individuals have developed coping strategies, there is a limit to the extent of broader community resilience that can be fostered through such individual efforts (Bele et al. 2013). A study conducted in 2008 in Cameroon showed that government institutions at the national level had not yet begun to work with local communities or local public institutions on issues related to climate change adaptation (Brown et al. 2010). Given the importance of rural local institutions in influencing livelihoods and adaptation of rural households, this study was conducted at the local level in three provinces of Cameroon to determine if and how local institutions were contributing to the resilience of local people to climate change.

\section{METHODS}

Using a mixed methodological approach, we conducted research in 13 villages in 3 provinces of Cameroon representing a range across the humid forest zone: Centre, East, and Southwest (Fig. 1). Villages were chosen for the research based on the presence of a Community Forest institution. In Cameroon a Community Forest is defined as a forest of approximately 5000 hectares in the nonpermanent forest domain that is subject to a management agreement between a village community and the administration in charge of forests (Djeumo 2001). Five villages were part of one Community Forest in Centre Province. In East Province there were two Community Forests, which consisted of three villages and one village, respectively. Four villages were included from Southwest Province, of which two were part of two Community Forests. Although we had been told that the two other villages were part of one of the Community Forests, we discovered on doing the surveys that this was not the case. The survey data from these villages are included in the research.

Surveys were administered face-to-face in each village, ensuring that both men and women of different ages and socioeconomic categories were included in the sample. Respondents were chosen at random, and only one individual from a household was surveyed. In some smaller villages, this meant that all households in the village were included. Surveys sought to determine the existence of informal and formal institutions that had an organizational form in each village and the membership of local people in these institutions. Information was collected on the main types of activities that each of these institutions carried out. Respondents were asked if they, or the local institutions that they were a member of, participated in activities or received information from local institutions external to the village related to forests, agriculture, or climate change. We also sought to understand the nature of the activities or information. Eighty surveys were administered in each of the Centre and East provinces, and 72 surveys were done in Southwest Province from May to July 2011 (Table 1). In total, 232 surveys were conducted with individuals from different households, ranging in age from 18 to 77 years, of which $47.4 \%$ self-identified as women. Data analysis included descriptive statistics and explored differences based on province and sex using SPSS Crosstabs with a Pearson chi-squared test.

Fig. 1. Location of research areas in Cameroon.

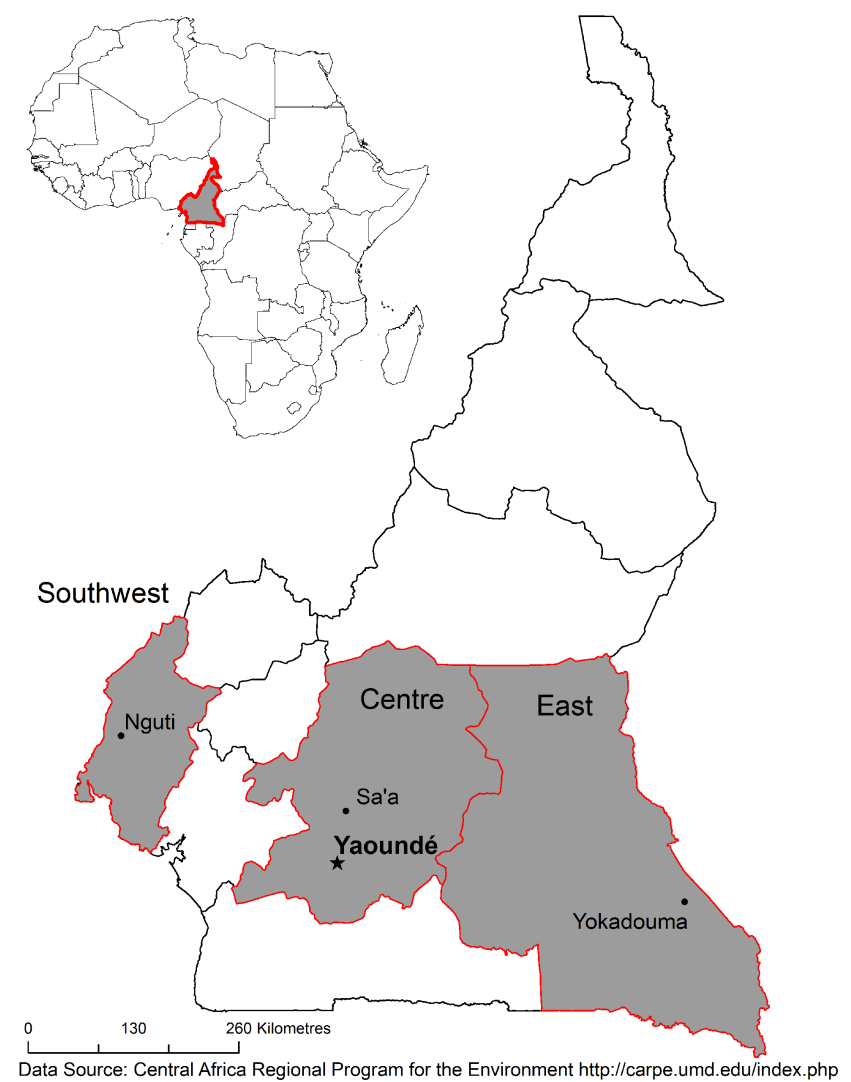

Table 1. Summary of data collection.

\begin{tabular}{lcccc}
\hline \hline & $\begin{array}{c}\text { Central } \\
\text { Province }\end{array}$ & $\begin{array}{c}\text { Eastern } \\
\text { Province }\end{array}$ & $\begin{array}{c}\text { Southwest } \\
\text { Province }\end{array}$ & Total \\
\hline Villages & 5 & 4 & 4 & 13 \\
$\begin{array}{l}\text { Community } \\
\text { Forests }\end{array}$ & 1 & 2 & 2 & 5 \\
$\begin{array}{l}\text { Household } \\
\text { Survey }\end{array}$ & 80 & 80 & 72 & 232 \\
$\begin{array}{l}\text { Respondents } \\
\text { Interviews }\end{array}$ & 5 & 13 & 8 & 26 \\
\hline
\end{tabular}


Semistructured interviews were conducted with representatives of local institutions who had some responsibility for agriculture, forests, conservation, or development. Private-sector institutions included not-for-profit or service organizations, primarily nongovernmental organizations (NGOs). We sought to determine the type of activities that these institutions were carrying out and how the institutions linked with local villages, other local institutions, and outside institutions at the national or international level. An emphasis was placed on investigating any interventions that could play a role in climate change adaptation. In total 26 interviews were conducted. Unfortunately, it was not possible to obtain interviews with all of the same public institutions in each province. Interviews were conducted from May to July 2011 and in July and August 2012. Qualitative analysis of the interview data was done to identify, code, and categorize the patterns following the key themes of action with local villages related to forests, agriculture, and climate change (Patton 2002). Key informants in each research area with knowledge of the context provided additional information about the informal village institutions and formal institutions related to agriculture, forests, conservation, or development. Project documents and reports from Community Forests and NGOs were also reviewed to determine any additional institutional activities or linkages in the study areas.

\section{RESULTS}

Most survey respondents $(84.1 \%)$ stated that their main occupation was farming, with an additional 3.5\% considering themselves first as "planters," meaning that they had a cacao or coffee plantation. It should be noted that, although respondents may have identified themselves as having another occupation, normally all villagers have an agricultural field. Annual or perennial food crops are grown in local fields as well as cacao, coffee, or oil palm as cash crops. The cash crops are often grown in agroforests together with food crops.

\section{Membership in local village institutions}

Survey results showed that respondents were members of diverse formal and informal institutions in each village (Table 2). These institutions or groups generally have been formed around a common interest or need of the members. The groups have an organizational structure, but are considered informal because they have not taken steps to be legalized according to Cameroonian law. Some institutions, e.g., Common Initiative Groups (CIGs), were formally legalized by the state. A large number of respondents $(33.5 \%)$ were members of informal savings and loan groups, commonly called tontines or njangi, where typically the members contribute a set amount of money on a weekly basis.

Similarly, a large number of respondents $(33.5 \%)$ were members of informal or formal groups to collect nontimber forest products (NTFPs) or grow annual food crops and sell them as a group. Such groups are a way to enhance the income of individual members from the collective marketing of these products. Respondents $(8.8 \%)$ were also part of other informal groups in which the members sold items collectively, but the respondents did not specify the types of items that were sold.
Table 2. Types of local institutions present in villages within each province (percentage).

\begin{tabular}{lcccc}
\hline \hline Type & $\begin{array}{c}\text { Central } \\
\text { Province }\end{array}$ & $\begin{array}{c}\text { East } \\
\text { Province }\end{array}$ & $\begin{array}{c}\text { Southwest } \\
\text { Province }\end{array}$ & $\begin{array}{c}\text { All } \\
\text { Provinces }\end{array}$ \\
\hline Savings and Loan & 54.6 & 9.6 & 21.2 & 33.5 \\
Collecting/Growing/ & 17.2 & 63.9 & 34.7 & 33.5 \\
Marketing & & & & \\
Family or Ethnic & 0 & 2.4 & 28.8 & 9.9 \\
Association & & & & \\
Group Marketing & 16.0 & 7.2 & 0 & 8.8 \\
Community Forest & 0 & 10.8 & 1.7 & 3.0 \\
Exploitation & & & & \\
Taxi Union & 1.8 & 3.6 & 3.4 & 2.7 \\
Faith-based Activities & 1.2 & 0 & 3.4 & 1.6 \\
Sawing Lumber & 3.1 & 0 & 0 & 1.4 \\
Community General & 0 & 0 & 4.2 & 1.4 \\
Maintenance & & & & \\
Cocoa Processing & 1.8 & 0 & 0.8 & 1.1 \\
Group Rental Service & 2.5 & 0 & 0 & 1.1 \\
Fishing & 1.2 & 0 & 0 & 0.5 \\
Kitchen Furnishing & 0 & 0 & 1.7 & 0.5 \\
Association & & & & \\
School Environment & 0.6 & 0 & 0 & 0.3 \\
Club & & & & \\
Other & 0 & 2.4 & 0 & 0.5 \\
\hline
\end{tabular}

Almost all $(95.6 \%)$ respondents were members of at least one group. Many respondents were members of more than one group, with some stating that they were part of four or five. The types of groups that existed in villages differed significantly $(p=0.000)$ based on gender and province. The most prominent difference between men and women was that women were more than twice as likely $(68.9 \%)$ to be members of savings and loan groups as men (31.1\%). Also more respondents in Centre Province were members of savings and loan groups than in the other two provinces (see Table 1). Collecting/growing and marketing groups were more prominent in East Province.

\section{Formal local institutions}

There were a variety of formal local institutions and external institutions that had some responsibility for agriculture, forests, conservation, or development in the research area (Table 3). The Community Forests were formed as associations, a cooperative, or a CIG. These are three of the four types of legal entities that are able to obtain a Community Forest in Cameroon (Djeumo 2001). These entities are governed by different laws and differ in their management structure. All must include the whole community concerned. Management of the Community Forest is done by a local management committee, which typically consists of retired civil servants or well-educated young men from the community (Brown and Lassoie 2010).

Another type of formal local institution is public institutions, primarily local agencies or arms of higher levels of government. The agencies that normally are responsible for aspects of agriculture, forests, conservation, or development in the research areas are the Ministry of Agriculture and Rural Development (MINADER), the Ministry of Forests and Wildlife (MINFOF), 
and the Ministry of Women's Empowerment and the Family (MINPROFF; see Table 4). The offices for these institutions were located outside of the research villages, typically in the capital of the subdivision. Personnel visited villages within their jurisdiction occasionally. Given the vastness of their areas of responsibility and limits of personnel, transport, and operating budgets, they did not visit any one village very frequently.

Table 3. Types of formal local institutions in research area.

\begin{tabular}{ll}
\hline \hline Type & Description \\
\hline Village Council & $\begin{array}{l}\text { Headed by the local chief, which makes some } \\
\text { decisions related to allocation of land for agriculture } \\
\text { and exploitation of the village forest }\end{array}$
\end{tabular}

Family Part of the traditional decision-making structure of Meeting extended families

Community A forest of approximately 5000 hectares in the Forest nonpermanent forest domain, that is subject to a management agreement between a village community and the administration in charge of forests. Management of the Community Forest is done by a local management committee made up of representatives from the communities involved.

NGOs Typically formed based on the interest of the members, and focus on working in a charitable manner with local villagers on different issues related to sustainable community development, agricultural development, empowerment of women, forest and biodiversity conservation, community forest management.

Table 4. Summary of external institutions intervening in research area.

\begin{tabular}{|c|c|c|}
\hline $\begin{array}{c}\text { Local Government } \\
\text { Agency }\end{array}$ & $\begin{array}{l}\text { International } \\
\text { Organizations }\end{array}$ & $\begin{array}{c}\text { International } \\
\text { Research Centre }\end{array}$ \\
\hline $\begin{array}{c}\text { Ministry of } \\
\text { Agriculture and Rural } \\
\text { Development }\end{array}$ & $\begin{array}{l}\text { World Wide Fund for } \\
\text { Nature }\end{array}$ & $\begin{array}{c}\text { Center for } \\
\text { International } \\
\text { Forestry Research }\end{array}$ \\
\hline $\begin{array}{l}\text { Ministry of Forests } \\
\text { and Wildlife }\end{array}$ & $\begin{array}{l}\text { Wildlife Conservation } \\
\text { Society }\end{array}$ & $\begin{array}{c}\text { World Agroforestry } \\
\text { Center }\end{array}$ \\
\hline $\begin{array}{l}\text { Ministry of Women's } \\
\text { Empowerment and the } \\
\text { Family }\end{array}$ & $\begin{array}{c}\text { International Union } \\
\text { for Conservation of } \\
\text { Nature } \\
\text { SNV Netherlands } \\
\text { Development } \\
\text { Organization } \\
\text { Gesellschaft für } \\
\text { Internationale } \\
\text { Zusammenarbeit } \\
\text { (GIZ) }\end{array}$ & $\begin{array}{c}\text { International } \\
\text { Institute for Tropical } \\
\text { Agriculture }\end{array}$ \\
\hline
\end{tabular}

Other formal institutions that are not located in the villages, but intervene in the communities in a variety of ways, are not-forprofit organizations, primarily NGOs. These NGOs have been formed based on the interest of the members and focus on working in a charitable manner with local villagers on different issues related to sustainable community development. The number and focus of these NGOs differed between the provinces. Given the vastness of intact humid forest in East Province and the presence of several national parks, this has led to the development of many NGOs with a focus on aspects of conservation and sustainable development. One prominent NGO in the region, Le Réseau des Organisations Non-Gouvernementales Locale du Sud-Est Cameroun (ROSE), brings together a number of small NGOs to cooperate on local sustainable development initiatives. One of those NGOs that was particularly active in the region was primarily focused on the empowerment of women through sustainable development activities.

Some international institutions intervened in the research areas in various ways. These were international conservation organizations including the World Wide Fund for Nature (WWF), the Wildlife Conservation Society (WCS), and the International Union for Conservation of Nature (IUCN). WWF and IUCN were involved in East Province. WCS and WWF intervened in Southwest Province, particularly in the villages that were close to the Korup National Park. International research centers worked in Centre Province, namely the Center for International Forestry Research (CIFOR) and the International Institute for Tropical Agriculture (IITA). The World Agroforestry Center, CIFOR, and IITA worked in East Province.

International development institutions carried out many different types of development projects in Cameroon. SNV Netherlands Development Organization (SNV), was heavily involved in working in East Province (About Us; http://www.snvworld.org/ en/regions/world/about-us). The Gesellschaft für Internationale Zusammenarbeit (GIZ) also had some development projects in the study area (About GIZ; http://www.giz.de/en/html/about giz. html).

\section{Action related to natural resources and climate change}

\section{Perspective of formal local institutions}

The role of the local MINADER government agency is to support local farmers by providing advice, information, and sometimes new varieties of agricultural crops. These agents are often involved in providing expertise and technical support in management of diseases of cash crops like cacao. Sometimes they provide pesticides or equipment. Representatives of MINADER interviewed in the Centre and Southwest provinces indicated that they had not been involved in any workshops or received any information from the national level of MINADER related to farmers' concerns about the changing climate. The head of the local agency in Southwest province stated:

That is the problem I'm facing and the many questions they keep asking me till now. Before everything being equal we were receiving the first rains on 15th March. It never failed and people understood that in that period they could do their land preparations.... [Now] the rains come unpredictably so they don't know whether to plant in March or not. When they come to complain to me, I 


\begin{abstract}
just tell them to take a risk because I can't tell exactly when to plant. Sometimes you plant and the crops remain dried up in the soil. So Imyself do not know how to advise farmers.
\end{abstract}

The role of the local MINFOF agency is to control the illegal exploitation of forests and poaching in the subregion, both inside and outside protected areas. In this capacity the staff visit villages to raise awareness of the laws. They also provide support for Community Forests. MINFOF staff in Southwest Province indicated that they had not been involved in any workshops related to climate change. MINPROFF seeks to empower women and families to know their human rights and to improve their livelihoods. To this end, they encourage women to form CIGs and work together in agricultural development projects. Representatives indicated that they were not involved in any activities specifically related to climate change.

Local NGOs in all three areas carry out many sustainable development activities with local villages. These include fostering the development of local community development groups; projects relate to fish farming, improved processing and marketing of NTFPs, new varieties of agricultural crops, or improved management practices for production and storage of food and cash crops. For example, in Southwest Province, one NGO was working with local village groups to develop agroforestry systems that integrate various commercially important tree crops with improved varieties of annual crops. NGOs have provided the capacity for communities to follow the complex government process involved in obtaining a Community Forest. In East Province, one NGO was also involved in building the capacity in Community Forests for development of processing and marketing of NTFPs, transforming saw mill waste into charcoal, and development of tree nurseries for reforestation. Other activities of NGOs in East Province included capacity building for successful management of revenues from forest exploitation so that it contributes to the development of their communities.

Community Forests in the research areas have often been focused on management of the forest for exploitation of timber and marketing of forest resources. The benefits from these activities are supposed to be used for community development, but this is not always a successful or conflict-free process. However, it should be noted that some village wells and schools had been built in some areas as a result of revenue from the Community Forest. However, some Community Forests in the study area were not really functioning at the time of the research.

In Centre Province, the head of the Community Forest often was involved in raising awareness about climate change and the importance of trees for the global climate and local communities. This was done at community meetings and schools, primarily as a result of his personal initiative. This was not happening in other Community Forests. In the Southwest and East provinces, interviewees from Community Forests said that they were aware of changes in the climate, but they had not received any information or participated in workshops specifically related to climate change.

International NGOs like WWF, WCS, and IUCN provide financial and technical capacity for biodiversity conservation inside and outside protected areas located near some research villages. They also build capacity for sustainable forest management with Community Forests and government agencies. Their interventions for conservation and sustainable development projects are similar to those of, and often done in collaboration with, local NGOs. Similarly, international development institutions, e.g., GIZ and SNV, provide financial and technical capacity for sustainable community development. They are involved in various projects related to capacity building for Community Forest management, improvement of agriculture, or conservation.

International research centers, particularly CIFOR, have been involved in conducting research related to various aspects of forest management throughout Cameroon. CIFOR was involved in research on climate change in the study areas as part of the Congo Basin Forests and Climate Change Adaptation project, particularly in the East and Centre provinces. As a result of this research, they have provided information about climate change to NGOs and local villagers. In some cases they have held workshops for Community Forests and NGOs, particularly in the Centre and East provinces. In Southwest Province, one local NGO said that it had obtained information related to climate change from CIFOR while attending a workshop in the capital city of Yaoundé.

CIFOR has also been involved in working with some Community Forests in the East and Centre provinces on improvement of agricultural practices through introduction of new varieties of local crops, e.g., cassava. This was done in collaboration with IITA. Other projects such as development of small animal husbandry and mushroom cultivation sought to diversify livelihood strategies in the villages. These projects were done as a way to foster adaptation to climate change. The World Agroforestry Center has an active collaboration with NGOs to promote the domestication of some NTFPs such as Gnetum africanum. They have also been working with NGOs to develop the improved processing and marketing of NTFPs that people collect in the forest.

\section{Perspective of survey respondents}

Only $14.2 \%$ of all respondents indicated that they had participated in activities related to forests or agriculture with a government department. Similarly, only $14.7 \%$ of all respondents indicated that they had received such information from the government. These limited activities or information included agricultural production or processing, protected area management, and general government information. More respondents indicated that they participated in activities with $(53.5 \%)$, or received information from $(49.1 \%)$, an NGO related to forests and agriculture, primarily concerning agricultural production and processing of NTFPs.

Approximately one third of respondents (34.1\%) indicated that they had received information on or been involved in an activity specifically related to climate change. A large portion of these respondents $(45.6 \%)$, particularly in the Centre and East provinces, said that this was a result of participating in research done by students from CIFOR. Only in Centre Province did some respondents $(30.4 \%)$ indicate that they learned about climate change from the Community Forest institution. The workshops held in Centre Province were done in collaboration with CIFOR. 
Some respondents $(11.4 \%)$ indicated that they had received information about climate change from an NGO. No respondents indicated that they had been involved in climate change activities or received such information from the government.

\section{Fostering horizontal and vertical linkages}

Although the local MINFOF agency carries out the national mandates of MINFOF related to forest and wildlife management, there was limited or no communication from the national to the local level concerning climate change specifically. Similarly, although the local agency of MINADER carries out the mandates of the national level of MINADER related to agriculture and rural development, the representatives interviewed said that they had not received any information from the national level concerning climate change. Similarly, MINPROFF is the local agency for implementing national government policies and programs related to empowerment of women and protection of families. However, the national level of MINPROFF did not seem to be providing any information related to action on climate change.

Local NGOs work closely with local government administration and local government agencies related to the activities that they are doing. For example, NGOs work with MINFOF when helping a community to follow the process to obtain a Community Forest or to develop the required management plans. An NGO concerned with empowerment of women works with MINPROFF and MINADER to build capacity of women's groups for improved agricultural production and marketing. Community Forests also work with government institutions such as MINFOF on issues related to management of their forests. The Community Forest in Centre Province was working with MINADER on the agriculture diversification projects as described earlier.

External institutions, e.g., conservation NGOs or international development institutions, collaborate with the Cameroon government at the national level and with administrations at the local level in carrying out their development initiatives. When they hold workshops in the subregion, they often seek to build the capacity of local government agencies and invite local government staff to workshops. They tend to collaborate with local NGOs in carrying out their activities. For example, in East Province, SNV worked with ROSE because it brings together a number of NGOs that facilitate any capacity building, development, or funding that SNV provides for various initiatives.

\section{DISCUSSION}

In rural villages of Cameroon, there is a diversity of formal and informal institutions that relate to most aspects of rural life. At the village level, most collective action of local people appeared to be based on a common interest of improving their livelihoods or planning for future emergencies. Although none of the groups reported being involved in activities specifically related to climate change adaptation, the collective actions of the many growing/ collecting and marketing groups have the potential to increase the return on their individual labor. This can improve the economic status of local people and thus enable them to be more resilient to climate-related stresses. Furthermore, the savings and loan groups are a traditional way of providing insurance for future emergencies (Brown et al. 2007). Although this is often focused on saving for a health crisis or a death in the family, such groups could also be viewed as a strategy for climate change adaptation. Funds could potentially be used to provide food in a year when agricultural yields are low, or for investment in seed for planting in future years. The large number of women who are involved in the saving and loan groups is also important. Women are dependent on agricultural and forest resources for their livelihood and are often a marginalized group within society (Brown 2011, Molua 2011). These collective resources could be available to help them adapt to climate change.

The high percentage of membership in such village institutions is also a reflection of the social capital that is present within these communities. Membership, particularly in informal institutions such as labor-saving groups, has been seen as an indicator of the cognitive aspects of social capital such as trust, solidarity, and sharing (Krishna 2001, Narayan and Cassidy 2001). The presence of social capital in a community can facilitate the process of social learning, which fosters innovation and adaptation of technologies (Krishna and Uphoff 2002, Pretty and Buck 2002). Although groups in the research villages did not appear to be doing any activities related to climate change adaptation at the time of the research, the social connections that villagers have in these groups could foster the development and sharing of knowledge related to climate change adaptation in the future. Individuals contribute knowledge from their different backgrounds and are also connected to other novel information via their diverse social networks (Davidson-Hunt 2006). The fact that most people are members of more than one group further extends the opportunities for learning through their social networks. Although village groups do not tend to work together to address concerns, the overlap of diverse social interactions among groups could facilitate the learning of new information to help address concerns related to climate change adaptation. More research is needed to better understand the composition of groups and how this might be related to the exchange of knowledge for climate adaptation

The Community Forests as local institutions were not for the most part playing a direct role in climate adaptation. This is not really surprising because most Community Forests in Cameroon have focused on exploitation of timber. Although the sale of forest products can help to reduce poverty and contribute to the development of a community, thus fostering resilience to climate stresses, the socioeconomic and ecological outcomes of many Community Forests in Cameroon have been mixed (Oyono 2005, Brown and Lassoie 2010, de Blas et al. 2011). However, the presence of a Community Forest in a community does provide a link to external institutions working in the area of conservation and sustainable development. For example, CIFOR chose to conduct their climate change research in areas with Community Forests, which raised the awareness of local people about climate change. Beyond just information, this research also led in some cases to links with other external institutions, e.g., IITA, that provided improved varieties of agricultural crops. This provides a link for future sharing of innovations and knowledge.

Many local NGOs, with the support of international institutions, have facilitated the development of Community Forests in these areas and, therefore, continue to carry out many of their conservation and sustainable development activities in these 
villages. Such activities can build capacity for climate change adaptation through diversification of livelihood strategies, e.g., fish farming. They can also improve the overall economic status of local people by sharing knowledge on strategies to improve returns on agricultural and forest activities through improved processing, storage, and marketing. NGOs also encourage the formation of other village associations or groups so that local people will work together to improve their livelihood and sustainably use natural resources. In their interventions within villages, however, they did not necessarily work only with such groups. However, the presence of such groups provided a point of contact at the village level when planning any capacity-building activities. Training workshops might be open to any village member, but distribution of material, e.g., improved varieties of local food crops, might be limited to those who are members of a particular group. Although these linkages for sharing of knowledge and innovation could play an important role in fostering resilience for climate change adaptation, the reality is that NGOs are limited by a lack of trained personnel and the capacity to carry out activities in such vast areas.

Government agencies, although somewhat active on issues related to forests and agriculture, in reality have limited contact with people in the research villages, likely because of the small number of personnel and the size of their area of responsibility. A previous study at the national level indicated that national institutions related to agriculture, forest, conservation, or development were not linked with local communities on any activities related to climate change (Brown et al. 2010). This research confirmed that even several years later, local-level agencies of government were not being provided with any information from the national level related to climate change. This is a serious situation because government has an important role to play in building the capacity of local agents to respond to the changing circumstances. Although local people are already experiencing the effects of climate change, the local agents for agriculture did not know how to help them respond.

Given the dependence of women on natural resources that are sensitive to climate change, MINPROFF should be in a position to provide some support in helping women to respond. According to Molua (2011), women farmers in Cameroon are risk averse, which influences production outcomes and welfare. Because climate variability undermines agricultural development, it is important that government play a role in developing the capacity and strategies to help both men and women adapt. Given the mandate of the local forest agency, it may not be surprising that they have not received information related to climate change. However, with the preparations and discussion around REDD+ (Reducing emissions from deforestation and forest degradation in developing countries, and the role of conservation, sustainable management of forests, and enhancement of forest carbon stocks in developing countries) both globally and in Cameroon, capacity building for forest personnel in this area is important. Furthermore, with an increasing global focus on climate-smart landscapes for integration of mitigation and adaptation, capacitybuilding and collaboration among all government agencies concerned with natural resources is crucial (Harvey et al. 2014).

Therefore, although direct activities related to climate change adaptation were limited in the rural communities studied, the presence and density of membership in rural local institutions represent a strength that can be built on for future action. Given the absence of action by governmental institutions in responding to climate change, rural local institutions can stand in the gap. Research in Kenya demonstrated that local institutions reduce local vulnerabilities and increase livelihood security in areas experiencing climate variability (Washington-Ottombre and Pijanowski 2013). However, Community Forest institutions have limited potential for enhancing adaptive capacity because of their systemic problems. Their presence, however, does provide a point of contact for external institutions, which is of some value to those villages where they are located. The links that local NGOs and international institutions have with rural communities can facilitate the exchange of knowledge, but this should go beyond raising awareness to more focused climate adaptation interventions for both men and women. Ultimately in Cameroon, planning for climate change adaptation needs to promote the capacity of diverse local institutions and improve the relationships between local and national-level adaptation planning (Agrawal et al. 2012).

\section{CONCLUSIONS}

In the humid forest zone of Cameroon, studies indicate that climate change is already having an adverse impact on the livelihood strategies of rural men and women. People's adaptability and resilience in changing circumstances can be influenced by rural local institutions that learn and store knowledge and experience, and create flexibility in problem solving. Interactions between local and higher level institutions can also affect the capacity of a community to respond to change. Previous research in Cameroon showed that government institutions at the national level had not yet begun to work with local communities, or local public institutions, on issues related to climate change adaptation. Therefore, this study was conducted at the local level in three rural areas of Cameroon to determine if and how local institutions were contributing to community resilience to climate change.

In rural villages of Cameroon, there is a diversity of institutions that relate to most aspects of rural life, including savings and loan groups and collecting and marketing groups. Although these groups were not doing any specific activities related to climate change adaptation, the social connections and activities that villagers have in these groups could foster resilience in changing circumstances. There are also a variety of formal local institutions with some responsibility for agriculture, forests, conservation, or development in rural areas, namely Community Forests, NGOs, and local agencies of government. External institutions, e.g., development or conservation organizations and research centers, also intervene in communities. Unfortunately, local government agencies had not received any information from the national level of government to help them respond to people's concerns about climate change. They are often limited in their capacity to carry out their work in rural communities. Community Forest institutions are not playing a direct role in fostering resilience to climate change, but their presence in communities does provide a link for external institutions working or doing research in the area of conservation and sustainable development. This has the potential to build bridges with other institutions for future sharing of innovations and knowledge. 
In conclusion, given the absence of action by governmental institutions in responding to climate change, rural local institutions can stand in the gap. The linkage of households with local informal institutions fosters social learning, which builds adaptive capacity. The linkage of these institutions with other formal local and external institutions facilitates exchange of knowledge and resources that can foster resilience. However, given that forest-dependent communities are already experiencing the effects of climate change in Cameroon, it is necessary for the government to be active in planning for adaptation. One aspect of this planning should involve building the capacity of all local institutions to respond and improve the relationships between local and national-level adaptation planning.

Responses to this article can be read online at: http://www.ecologyandsociety.org/issues/responses. php/7327

\section{Acknowledgments:}

We would like to thank all the communities and institutions for giving time from their busy schedules to participate in the study. We also appreciate the help of the research assistant Germain Mbock. We thank Olufunso Somorin for fruitful discussions prior to beginning the research. We would like to thank Andrew Doiron for making the map for Figure 1. This research was conducted under the International Development Research Centre (IDRC) and Department for International Development (DFID) funded Congo Basin Forest Climate Change Adaptation project of the Center for International Forestry Research. Support was also provided from a Social Sciences and Humanities Research Council of Canada (SSHRC) Insight Development Grant.

\section{LITERATURE CITED}

African Ministerial Conference on Environment (AMCEN). 2011. Addressing climate change challenges in Africa: a practical guide towards sustainable development. United Nations Environment Programme, Nairobi, Kenya.

Agrawal, A. 2008. The role of local institutions in adaptation to climate change. International Forestry Resources and Institutions Program. IFRI Working Paper \#W08I-3. International Forestry Resources and Institutions Program, Ann Arbor, Michigan, USA.

Agrawal, A. 2010. Local institutions and adaptation to climate change. Pages 173-197 in R. Mearns and A. Norton, editors. Social dimensions of climate climate: equity and vulnerability in a warming world. World Bank, Washington, D.C., USA.

Agrawal, A., N. Perrin, A. Chhatre, C. S. Benson, and M. Kononen. 2012. Climate policy processes, local institutions, and adaptation actions: mechanisms of translation and influence. WIREs Climate Change 3(6):565-579. http://dx.doi.org/10.1002/ $\underline{\text { wcc. } 203}$

Bele, M. Y., A. M. Tiani, O. A. Somorin, and D. J. Sonwa. 2013. Exploring vulnerability and adaptation to climate change of communities in the forest zone of Cameroon. Climatic Change 119(3-4):875-889. http://dx.doi.org/10.1007/s10584-013-0738-Z
Berkes, F., J. Colding, and C. Folke. 2003. Navigating socialecologcial systems. Cambridge University Press, Cambridge, UK.

Bonan, G. B. 2008. Forests and climate change: forcings, feedbacks, and the climate benefits of forests. Science 320 (5882):1444-1449. http://dx.doi.org/10.1126/science.1155121

Brown, H. C. P. 2011. Gender, climate change and REDD+ in the Congo Basin forests of Central Africa. International Forestry Review 13(2):163-176. http://dx.doi.org/10.1505/146554811797406651

Brown, H. C. P., and J. P. Lassoie. 2010. Institutional choice and local legitimacy in community-based forest management: lessons from Cameroon. Environmental Conservation 37(3):261-269. http://dx.doi.org/10.1017/S0376892910000603

Brown, H. C. P., J. N. Nkem, D. J. Sonwa, and Y. Bele. 2010. Institutional adaptive capacity and climate change response in the Congo Basin forests of Cameroon. Mitigation and Adaptation Strategies for Global Change 15(3):263-282. http://dx.doi. org/10.1007/s11027-010-9216-3

Brown, H. C. P., S. A. Wolf, and J. P. Lassoie. 2007. An analytic approach to structuring co-management of community forests in Cameroon. Progress in Development Studies 7(2):135-154. http:// dx.doi.org/10.1177/146499340600700204

Davidson-Hunt, I. J. 2006. Adaptive learning networks: developing resources managment knowledge through social learning forums. Human Ecology 34(4):593-614. http://dx.doi. org/10.1007/s10745-006-9009-1

de Blas, D. E., M. Ruiz-Pérez, and C. Vermeulen. 2011. Management conflicts in Cameroonian community forests. Ecology and Society 16(1): 8. [online] URL: http://www. ecologyandsociety.org/vol16/iss1/art8

Demetriades J., and E. Esplen. 2010. The gender dimensions of poverty and climate change adaptation. Pages 133-143 in R. Mearns and A. Norton, editors. Social dimensions of climate change: equity and vulnerability in a warming world. World Bank, Washington, D.C., USA. http://dx.doi.org/10.1111/j.1759-5436.2008. tb00473.x

Djeumo, A. 2001. The development of community forests in Cameroon: origins, current situation and constraints. Rural Development Forestry Network 25b:1-16.

Eastaugh, C. 2010. Climate change impacts on African forests and people. IUFRO Occasional Paper No. 24. International Union of Forest Research Organizations, Vienna, Austria.

Folke, C. 2006. Resilience: the emergence of a perspective for social-ecological systems analyses. Global Environmental Change 16(3):253-267. http://dx.doi.org/10.1016/j.gloenvcha.2006.04.002

Harvey, C. A., M. Chacón, C. I. Donatti, E. Garen, L. Hannah, A. Andrade, L. Bede, D. Brown, A. Calle, J. Chará, C. Clement, E. Gray, M. H. Hoang, P. Minang, A. M. Rodríguez, C. SeebergElverfeldt, B. Semroc, S. Shames, S. Smukler, E. Somarriba, E. Torquebiau, J. van Etten, and E. Wollenberg. 2014. Climate-smart landscapes: opportunities and challenges for integrating adaptation and mitigation in tropical agriculture. Conservation Letters 7(2):77-90. http://dx.doi.org/10.1111/conl.12066 
InterAcademy Council. 2004. Realizing the promise and potential of African agriculture. InterAcademy Council, Amsterdam, The Netherlands.

Krishna, A. 2001. Moving from the stock of social capital to the flow of benefits: the role of agency. World Development 29 (6):925-943. http://dx.doi.org/10.1016/S0305-750X(01)00020-1

Krishna, A., and N. Uphoff. 2002. Mapping and measuring social capital through assessment of collective action to conserve and develop watersheds in Rajasthan, India. Pages 85-124 in C. Grootaert and T. van Bastelaer, editors. The role of social capital in development: an empirical assessment. Cambridge University Press, Cambridge, UK. http://dx.doi.org/10.1017/ CBO9780511492600.005

Lebel, L., J. M. Anderies, B. Campbell, C. Folke, S. HatfieldDodds, T. P. Hughes, and J. Wilson. 2006. Governance and the capacity to manage resilience in regional social-ecological systems. Ecology and Society 11(1): 19. [online] URL: http://www. ecologyandsociety.org/vol11/iss1/art19

Molua, E. L. 2011. Farm income, gender differentials and climate risk in Cameroon: typology of male and female adaptation options across agroecologies. Sustainability Science 6(1):21-35. http://dx.doi.org/10.1007/s11625-010-0123-Z

Mwangi E., R. Meinzen-Dick, and Y. Sun. 2011. Gender and sustainable forest managment in East Africa and Latin America. Ecology and Society 16(1): 17. [online] URL: http://www. ecologyandsociety.org/vol16/iss1/art17/

Narayan, D., and M. F. Cassidy. 2001. A dimensional approach to measuring social capital: development and validation of a social capital inventory. Current Sociology 49(2):59-102. http:// dx.doi.org/10.1177/0011392101049002006

Ostrom, E. 2005. Understanding institutional diversity. Princeton University Press, Princeton, New Jersey, USA.

Oyono, P. R. 2005. Profiling local-level outcomes of environmental decentralizations: the case of Cameroon's forests in the Congo Basin. Journal of Environment \& Development 14 (2):1-21.

Patton, M. Q. 2002. Qualitative research and evaluation methods. Third edition. Sage, Thousand Oaks, California, USA.

Pretty, J., and L. Buck. 2002. Social capital and social learning in the process of natural resource management. Pages 23-34 in C. B. Barrett, F. Place, and A. A. Aboud, editors. Natural resources management in African agriculture: understanding and improving current practices. CAB International, Wallingford, UK. http://dx. doi.org/10.1079/9780851995847.0023

Republic of Cameroon. 2005. Document de stratégie de développment du secteur rurale. Republic of Cameroon, Yaoundé, Cameroon.

Schlenker, W., and D. B. Lobell. 2010. Robust negative impacts of climate change on African agriculture. Environmental Research Letters 5:01410. http://dx.doi.org/10.1088/1748-9326/5/1/014010
Sonwa, D. J., O. A. Somorin, C. Jum, M. Y. Bele, and J. N. Nkem. 2012. Vulnerability, forest-related sectors and climate change adaptation: the case of Cameroon. Forest Policy and Economics 23:1-9. http://dx.doi.org/10.1016/j.forpol.2012.06.009

Tompkins, E. L., and W. N. Adger. 2004. Does adaptive management of natural resources enhance resilience to climate change? Ecology and Society 9(2): 10. [online] URL: http://www. ecologyandsociety.org/vo19/iss2/art10/

Uphoff, N., and L. Buck. 2006. Strengthening rural local institutional capacities for sustainable livelihoods and equitable development. World Bank, Washington, D.C., USA.

Vermeulen, S. J., P. K. Aggarwal, A. Ainslie, C. Angelone, B. M. Campbell, A. J. Challinor, J. W. Hansen, J. S. I. Ingram, A. Jarvis, P. Kristjanson, C. Lau, G. C. Nelson, P. K. Thornton, and E. Wollenberg. 2012. Options for support to agriculture and food security under climate change. Environmental Science \& Policy 15 (1):136-144. http://dx.doi.org/10.1016/j.envsci.2011.09.003

Walker, B., L. Gunderson, A. Kinzig, C. Folke, S. Carpenter, and L. Schultz. 2006. A handful of heuristics and some propositions for understanding resilience in social-ecological systems. Ecology and Society 11(1): 13. [online] URL: http://www.ecologyandsociety. org/vol11/iss 1/art13/

Washington-Ottombre, C., and B. C. Pijanowski. 2013. Rural organizations and adaptation to climate change and variability in rural Kenya. Regional Environmental Change 13(3):537-550. http://dx.doi.org/10.1007/s10113-012-0343-0 